\title{
CASE STUDIES ON THE DOWNSIDE OF TRANSACTIONAL AND AUTHORATITATIVE ORGANIZATIONAL LEADERSHIP STYLES DURING CRISIS MANAGEMENT
}

\author{
Vehbi GÖRGÜLÜ \\ İstanbul Bilgi Üniversitesi, Türkiye \\ vehbi.gorgulu@bilgi.edu.tr \\ https://orcid.org/0000-0001-6248-7289
}

\begin{abstract}
Leadership is a value gained through education and experience. Leadership communication has the potential make corporate communications and risk management processes more dynamic and efficient. From these aspects, leader communication can be very influential over sustainability of corporate success. The current study aims to explore how authoritative and transactional leadership styles result with various challenges during crisis communication and management. The crises experienced by The Martha Stewart Living Omnimedia, Toyota, Facebook and the United Airlines companies are explored as case studies. The analysis is not limited with the crisis processes, but also questions the efficiency of leadership models embraced by managers of these two organizations.
\end{abstract}

Keywords: Leadership, Martha Stewart, United Airlines, Facebook, Crisis Management.

\section{OTORITTER VE SÜRDÜRÜMCÜ (TRANSAKSIYYONEL) LIDERLIK YAKLAŞIMLARININ KRIZZ YÖNETIMİ BAĞLAMINDAKİ KISITLILIKLARI ÜZERINE VAKA INCELEMELERİ}

\section{ÖZ}

Liderlik doğuştan değil, eğitim ve deneyimle edinilen bir değer olarak kurumsal hayatta karşımıza çıkmaktadır. Etkili lider iletişimi, yalnızca kurumsal iletişim sürecini verimli kılmamakta, aynı zamanda kriz yönetim süreçlerinin de başarıyla sonuçlanmasını sağlamaktadır. Tüm bu yönleriyle, etkili lider iletişiminin şirketlerin geleceği üzerinde belirleyici olduğu vurgulanabilir. Mevcut çalışma, otoriter ve transaksiyonel liderlik modelleri ile kriz yönetim süreçleri arasındaki ilişkiyi incelemektedir. Belirlenen ilişkinin incelenebilmesi için seçilen vakalar The Martha Stewart Living Omnimedia Company, Toyota, Facebook ve The United Airlines skandalları olmuştur. Mevcut değerlendirme, yalnızca kriz süreçlerine yoğunlaşmamakta, aynı zamanda kurumsal liderlerin kriz iletişimini ve yönetimini ne şekilde gerçekleştirdiklerini eleştirel bir bakış açısıyla incelemektedir.

Anahtar Kelimeler: Liderlik, Martha Stewart, United Airlines, Facebook, Kriz Yönetimi.

\section{INTRODUCTION}

Leadership has become one of the most important components of corporate communication. However, leadership practice is not only limited with top executives of companies. The concept is also relevant for junior executives, as well as politicians, opinion leaders and artists. Today, companies aim to hire employees with leadership qualities, who can make unique contributions to the organization during teamwork processes such as strategic planning, product development and marketing. 
Leadership has been at the focus of academic researchers, since the beginning of 1920s. While leadership was defined as the sense of creating obedience, loyalty and cooperation in 1920s (Moore, 1927), it was conceptualized as a personality trait that was mainly identified with the power of influence in 1930s. Studies in 1940 explained leadership as the power to lead group actions with persuasion (i.e., Hemphill, 1949). In 1960s, leadership was perceived as an attribute of influencing and leading individuals towards the achievements of common goals and interests (Seeman, 1960). It was in 1970s, when leadership was included within the framework of organizational behavior studies. According to Burns (1978), 1970s marked the maturity stage of capitalism, during which more formal institutional structures among corporations were achieved. The theorist (1978) defined leadership as the art of mobilizing employees in line with corporate values and goals, by using social, economic and political resources efficiently. The theorist propounded a new concept titled transformative leadership, which associated act of leading with organizational transformation. According to this concept, leaders could only reach success, if they created an interactive environment among organization employees and external stakeholders (Burns, 1978). From this perspective, it can be said that Burns' approach toward leadership showed differentiations from previous definitions. Burns was the first leadership scholar, that treated leadership as a two-way process, in which feedback from recipients played key role for successful operation.

When it comes to $21^{\text {st }}$ century, it can be seen that three leadership approaches are on the rise at academic level; namely, spiritual leadership, servant leadership and transcendental leadership models. In spiritual leadership, the unique personal qualities of individuals are emphasized, while transcendental leadership is associated with addressing senses and emotions of others' through motivation. Lastly, servant leader is perceived as a compassionate figure that prioritizes the demands of her/his stakeholders.

The current study aims to explore authoritative and transactional leadership models during crisis management processes. As case studies, the crises experienced by The Martha Stewart Living Omnimedia, Toyota, Facebook and the United Airlines companies are taken into consideration. The exploration is not limited what happened during the crisis process, but mainly aims to focus on the effectiveness of leadership models embraced by top managers of two companies.

\section{LITERATURE REVIEW: COMMUNICATING AND MANAGING THE CRISIS}

Crisis is related to unexpected social, economic and cultural events that require urgent solutions. Changing social trends, technological innovations, market dynamics, products and customer expectations can all result with crisis situations.

Previous literature on crisis communication and management reveal that the phenomenon is described from different perspectives. While Balaban (2018, p.5) defines crisis as a "situation that threatens the existence of an organization by creating high level of stress", Jackson-Cherry and Erford (2017) describe the phenomena as unexpected events that negatively affect the existing order within the organization. Theorists emphasize that even though crisis are low probability events, when they occur, they can create high impact, and even lead to chaos (Jackson-Cherry \& Erford, 2017). According to Coombs (2007), crisis are unexpected events that threatens stakeholders and affect organization performance negatively. Similarly, Özdemir (2017) states that "crises are unpredictable, disrupting the organization of the institution by threatening its goals, value and operation" (p. 112). In order to qualify an event as a crisis, there must be a dangerous situation that will cause a change and a threat against the existence of the organization. Daily disruptions cannot be associated with crisis. In order to identify an experience as a crisis, it should have features such as threatening the existence of the organization, unpredictability, urgent intervention, bringing sudden changes, creating tension and causing panic. Measures can be taken to prevent the crisis, but it cannot be prevented completely. The most important feature is uncertainty (Coombs, 2007). As the uncertainty accelerates, it increases the emergence of a potential crisis.

Submit Date: 20.07.2020, Acceptance Date: 03.09.2020, DOI NO:10.7456/11004100/020

Research Article - This article was checked by iThenticate

Copyright (C) The Turkish Online Journal of Design, Art and Communication 
Another key feature is the time limitation, as a crisis also has the potential to challenge material (production-based) and motivational (employee-based) resources. The characteristics of the crises vary according to the industry the organization belongs (Balaban, 2018). Managers and leaders who perceive the danger of the crisis in the right time are enabled to take necessary measures that would lead to less damages in the long term.

Various categorizations have been made regarding the crisis communication and management process. A crisis is not an instant situation; it consists of several stages. According to Coombs (2007), these stages are; pre-crisis period, crisis period and post-crisis period (Coombs, 2007); while Dirlik (2018) presents a different categorization, composed of five phases: blindness, inertia phase, wrong action, crisis stage and termination (p. 18). Both theorists emphasize that businesses have to deal with many negative situations not only during but also after the negative experience encountered. These situations do not only have negative economic consequences, but also problems related with loss of corporate reputation and trust (Coombs, 2007; Dirlik, 2018). The responsibility of organizational leaders and managers is to survive the crisis process with minimal damage, by detecting early signals when possible.

Another categorization is presented by Ulutaş (2010), who classifies crisis management as active and reactive crisis (p. 22). In active crisis management; the crisis management team of the organization makes preparations for taking precautionary measures before the crisis. Reactive crisis management can be explained as reducing the company's losses to the lowest level possible, during the post-crisis period.

Deriving from mentioned definitions and classifications, one can state it is possible for enterprises to apply two basic approaches in crisis management activities, namely avoiding crisis and resolving the crisis. While avoiding the crisis is the avoidance of decisions that will pose a risk to abstain from the crisis; solving the crisis, is related with examining the internal and external environment, determining the crisis, neutralizing it or turning it into an opportunity. Organizational leaders play a key role in this process, for being decision makers.

\section{Leadership}

Each action taken by corporate leaders determines the fate of their organization. The quality of the entire relationship networks established with stakeholders such as company employees, investors, shareholders, consumers and non-governmental organizations of the field directs the future of the company. Moreover, this whole network of relationships is not limited to local and national bases. With the acceleration of globalization in the mid-1990s, it is observed that the companies operating on a national basis have increased their interactions with international stakeholders (Tichy \& Devanna, 1996).

Among these complex relationships, one of the most important concerns for senior executives of national and multinational companies has been to protect their companies' reputation. Establishing a company's reputation and making it sustainable are among the basic job descriptions of senior corporate communication managers.

Although the importance of corporate communication and, specifically, corporate reputation have already been noticed by the management team of various companies, some experiences indicate that uncertainties remain in terms of what communicative terms to expect from corporate leaders. This situation is a result of underestimating the value and importance of corporate communication. For example, in several past experiences, such as the United Airlines scandal, where CEOs have lost their managerial control, they appeared to be unaware of the organization's strategic planning and could not efficiently evaluate the events within and around the organization (Sebastian, 2015). Due

Submit Date: 20.07.2020, Acceptance Date: 03.09.2020, DOI NO:10.7456/11004100/020

Research Article - This article was checked by iThenticate

Copyright (C) The Turkish Online Journal of Design, Art and Communication 
to these reasons, CEOs have not been able to see how such factors negatively affect their company's operations and financial status. However, when effective examples, in which there are strong ties between corporate communicators and senior executives are taken into consideration, it can be seen how this process provides efficiency for both parties. These ties do not only prevent communicationbased deficiencies or miscommunication, but also provide a basis for strengthening the communicative impact of corporate leaders.

Leadership models have different qualities when it comes to sustaining such strength. In this study, the strategies and main characteristics of authoritative and transaction leadership styles will remain at the focus.

\section{Authoritative Leadership Style}

Authoritarian leadership, which takes its ground from the power of the leader, can be defined as the form of leadership in which an individual is the sole authority in all decision-making processes. In organizations dominated by authoritarian leadership, the potential of employees or other stakeholders to influence decision-making is limited. The authority figure, which is the leader, rarely needs the suggestions of the stakeholders when making decisions on behalf of all its stakeholders (Hogg \& Adelman, 2013). In this sense, it can be said that the authoritarian leader also has a strong control and supervision mechanism over his stakeholders (Hogg \& Adelman, 2013).

In authoritarian leadership, the authority stems from the power of the authority figure. At this point, it would be appropriate to briefly discuss the notion that is addressed as power. While power comes to the fore as an inspiring phenomenon that individuals can easily be influenced by, it can also make individuals nervous due to its controlling nature. For example, according to Diamond (2016), power is a taboo subject just like death and sexuality; therefore, not everyone is feeling comfortable when talking about power. When examining a leader in authority, it is necessary to evaluate how she or he acquired that power and for what purposes (Wang \& Guan, 2018).

Power is defined as the art of influencing the masses (Guo et al., 2018). It is not possible to talk about leadership without power. But it should be noted that having the ability to influence the masses is not enough for leadership (Li \& Sun, 2015). Power must also be used to realize common interests and expectations. For example, when a thief with an armed hand who enters the house where a married couple lives to take a robbery, he may silence the household by threatening them. In this scenario, the thief holds the power; because if household members do not listen to him, he may open fire. Having power does not make the thief a leader; because in this scenario, the thief performs an act that can be considered a crime in his own interests and by ignoring the laws. It is precisely for this reason that the use of power ethically, effectively and accurately lies at the core of leadership. In Gladwell's (2008) words, "intelligent use of power will bring leadership" (p. 23).

While authoritarian leadership is an effective form of management in the traditional leadership literature, it also comes up with several deficiencies, especially in the context of modern organizations (Rosener, 2011). Although authoritarian leadership has advantages such as rapid decision-making, operations, and effective implementation of control and supervision mechanisms, this leadership model may occasionally bring problems including arbitrary decision making, centralized management mechanism and less participatory working atmosphere. The impact of practicing authoritative leadership in modern corporations will be assessed by taking the cases with Martha Stewart Living Omnimedia and Toyota companies into consideration.

\section{Transactional Leadership Style}

Transactional leaders aim to increase the productivity of their organizations by motivating their employees through establishing effective reward mechanisms. Transactional leadership is efficient

Research Article - This article was checked by iThenticate 
in terms of sustaining stable performance and reaching organizational goals (Bass et al., 2003) Transactional leadership is also fruitful in terms of sustaining financial growth and savings via intense managerial control mechanisms. However, managers who embrace transactional leadership style often avoid taking risks and focus on regular administrative processes if they do not encounter an extraordinary situation (Bono \& Judge, 2004). Young et al. (2020) argue that transactional leadership loses its validity and ground, as recent generations such as Generation Y and Generation $\mathrm{Z}$ are having different work motivations based on social satisfaction. Especially Generation $\mathrm{Z}$ is mainly motivated when what they do for work creates a social value (Kirchmayer \& Fratricova, 2020).

Table 1. A comparison of transactional and transformative leadership traits

\begin{tabular}{|l|c|c|}
\hline Leadership style & Transactional & Transformative \\
\hline $\begin{array}{c}\text { Time management } \\
\text { Communication }\end{array}$ & Short-term oriented & Long-term oriented \\
\hline Focus & Vertical & Horizontal \\
\hline ewarding mechanism & Finance-oriented & Consumer-oriented \\
\hline Source of power & External & Internal \\
\hline Decision making & Position & Reputation \\
\hline $\begin{array}{l}\text { Openness to change } \\
\text { Work division }\end{array}$ & Centralized & Participatory \\
\hline Control mechanism & Status quo-oriented & Open to change \\
\hline
\end{tabular}

Source: Tichy \& Devanna (1996).

Due to these features, transactional leadership by itself may remain insufficient. However, its opposite, transformational leadership can be said to be quite effective when applied in conjunction with conventional transactional leadership practices (Shields \& Hesbol, 2020). In transactional leadership, the needs of the lower ranks in Maslow's hierarchy are responded, while in transformational leadership, the focus is at higher ranks. The transformative leader appears as an inspiring figure for those around him, who guide them to actualize themselves through work. In a scenario where both transactional and transformational leadership practices are applied, the leader will adopt an integrated approach that ensures the sustainability of business operations, while creating value for those around her/him. John F. Kennedy and Abraham Lincoln are early examples of leaders who combined both approaches, for both being socially influential figures and successful transactional business people (Kirchmayer \& Fratricova, 2020).

It is worth noting that there are important differences between transactional and transformational leadership models. Transactional leaders focus on achieving short-term goals, while transformational leaders focus on long-term goals within the framework of their vision and the values of their organization (Tichy \& Devanna, 1986). In decision-making processes, transactional leaders take a centralized approach, while transformational leaders perform decision-making processes as participants (Shields, 2020).

\section{METHODOLOGY AND FINDINGS}

For the current study, the case study method is applied to assess the effectiveness of transactional and authoritative leadership styles in corporations during crisis management processes. Case study is a method of obtaining information by examining past experiences and environment related to an event and by conducting in-depth research (Stake, 1978). Case study method is used to obtain detailed information about an individual's or an organization's psychological / psychiatric status. The information sources analyzed in the current study consists of secondary resources, namely, financial data, news pieces, interviews and memoirs. 


\section{The Case with Martha Stewart Living Omnimedia Company}

Martha Stewart, who was born in 1941, completed her education in architecture in 1960s. Despite her profession, she started working as a stockbroker and remained active in Wall Street until mid 1970s (James \& Lane, 2020). After she moved to Connecticut, Stewart started improving her skills in culinary and established her own catering company called Stewart's Limited. In less than ten years, Stewart became one of the most sought people in catering business, which enabled her to make more than $\$ 1$ million profit in return. As a consequence of her rising popularity, Stewart started writing her own cook books, and became a best-seller author all around the world (Byron, 2002).

Stewart, as an entrepreneur, received her main success in 1997, when she established Martha Stewart Living Omnimedia Company (Byron, 2002). Her company's operations focused on publishing Stewart's cookbooks, lifestyle magazines and television broadcasting productions. As the company decided to go public in 1999, the value of her cookbooks reached more than $\$ 1.8$ billion, which turned into a large investment tool (Allen, 2006). To date, Stewart remains one of the most influential investors based in America, who created a billion-dollar worth business (Allen, 2006). As one of the richest investors of the United States, Stewart is mainly known for her meticulous and authoritative personality (Byron, 2002). The employees of Martha Stewart Living Omnimedia also underlines the fact that Stewart is a perfectionist, which at times results with pressures over their shoulders (Future of Working, 2015).

Despite her financial success and worldwide reputation, the wheels had come off in 2002 when Stewart's name was involved in a financial scandal (Sebastian, 2015). Stewart bought shares of the ImClone Company, who was producing medicine for cancer treatment. It was found suspicious, as Stewart bought shares of the company the day before Food and Drug Administration of the United States stated the medicines produced by ImClone Company were not yet approved (Hays, 2004). Due to the timing and the $\$ 45.000$ income drawn, Stewart was accused of irregularity and received imprisonment penalty.

Table 2. Annual profits of Martha Stewart Living Omnimedia Company (1999-2004)

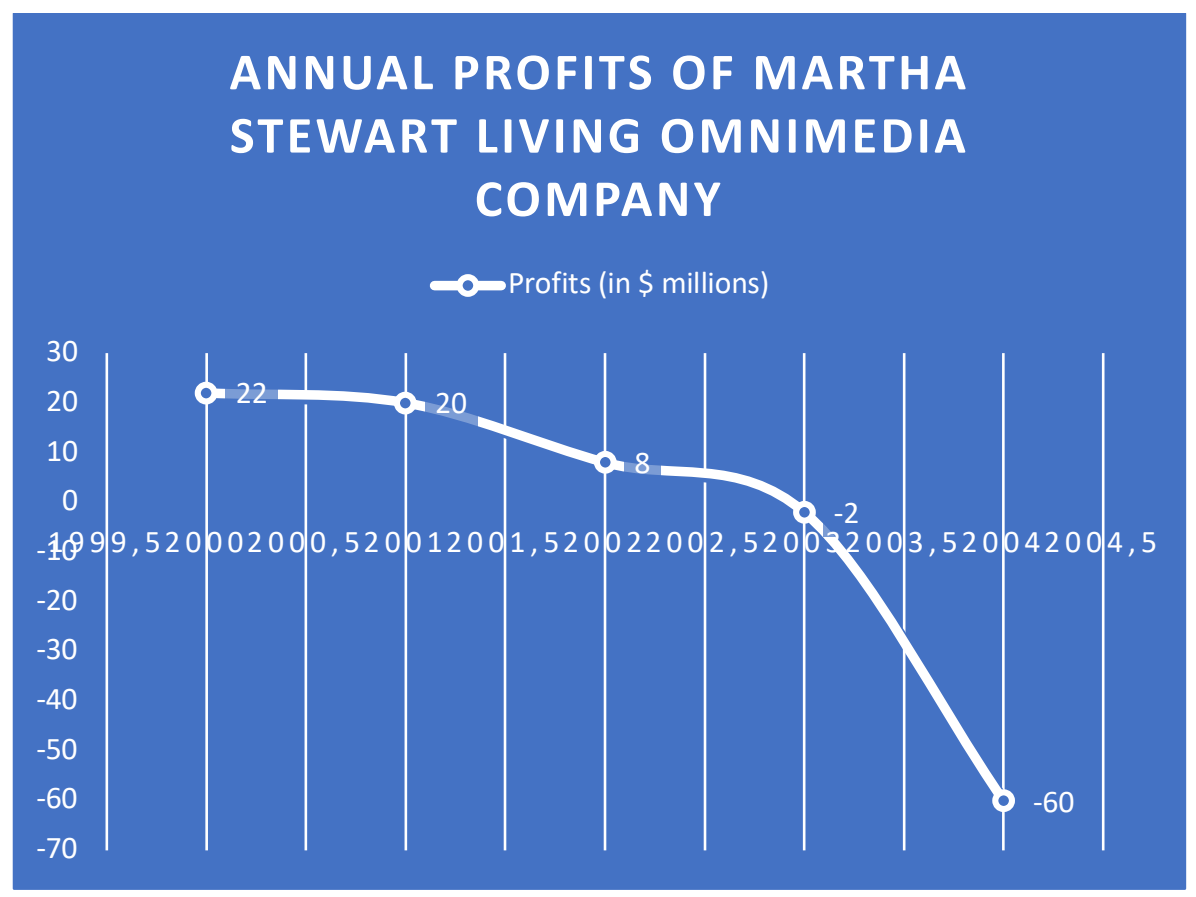

Source: NBC (2004)

Research Article - This article was checked by iThenticate

Copyright (C) The Turkish Online Journal of Design, Art and Communication 
Following the scandal, stock shares of Martha Stewart's own company Living Omnimedia started to lose value in the stock market drastically. While the value of a single Martha Stewart Living Omnimedia Company stock was $\$ 30$ in 2005, it decreased to $\$ 8$ in 2008 (Ledbetter, 2008). The company continued losing its market value until 2015, when Stewart had to sell her company to a retailer company, Sequential Brand Group (Sebastian, 2015).

As a celebrity entrepreneur, who remains as an influential figure especially in the eyes of the American housewives, it was disappointing for Stewart to be recognized as a prisoner (Hays, 2004). Following the scandal, Stewart stated "whatever happened to me should not affect my company" (Hays, 2004). Still, this was not quite possible, as Martha Stewart Living Omnimedia Company was completely based on Stewart's persona. Findings of public opinion surveys that aimed to estimate the impact of the scandal on Stewart's company also supported the argument that Stewart was the first figure that fans associated with the Martha Stewart Living Omnimedia company (The Economist, 2003).

Table 3. Overview of Martha Stewart Living Omnimedia share price (1999-2003)

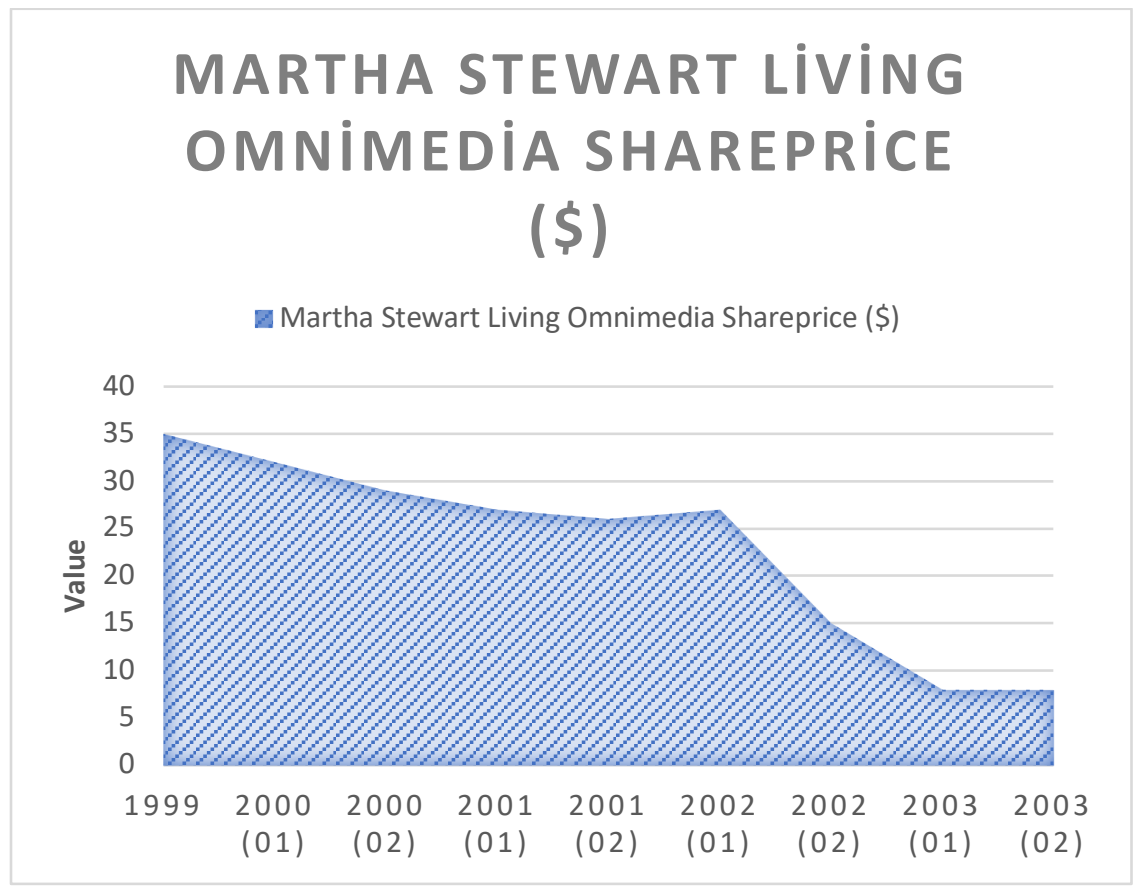

Source: The Economist (2003)

Studies conducted by Siena University and The Washington Post revealed the Stewart and her company did not only lose reputation in the eyes of the public, but also among other stakeholders such as her company's investors and distributors (White \& Masters, 2004).

While examining Stewart's management style and the dynamics of her company, one can observe that Stewart has embraced authoritative leadership style. Authoritative leadership style is efficient when a manager aims to have overall control over her/his company's daily operations, but it can come up with unexpected consequences as well. One of Stewart's statements following the scandal, also points out to her authoritarian attitude towards her stakeholders: "I wish I paid attention to what my financial consultants told me" (Jerome, et al., 2007).

Another problem regarding the Living Omnimedia Scandal was related with Stewart's silence throughout the crisis process, which increased negative reactions towards her especially among the American citizens (Jerome et al., 2007). With the assumption that she was the only person that could

Research Article - This article was checked by iThenticate 
survive her company, Stewart focused on finding a solution to find an end to her financial loss and neglected the fact that crisis communication was also part of this survival process. Thus, Stewart's experience reveals that despite authoritative leadership style provides opportunities in terms of disciplined supervision and fast decision-making mechanism, it sometimes results with neglection of communication, consultancy and feedback mechanisms.

\section{The Case with Toyota}

The Nagoya-based Toyota Company is one of the most well-grounded automobile producers in the world. Started its operation as part of the Automatic Loom Works in 1933, the company produced its first car, Model AA, in 1936 (Toyota Resmi İnternet Sitesi, 2019). The second world war negatively affected the company operations which had to be slowed down by 1945 (Toyota Resmi Internet Sitesi, 2019). The company's operations regained momentum in 1950s, when the Toyota CEOs started travelling across the United States to keep up with the world's best producers such as Ford Motor Company (Toyotaky, 2019). Inspired by the high-tech Ford automobiles, the company launched its second car, called Toyopet, which was aimed to appeal to especially the American consumers. The success of Toyopet was followed by the release of the Land Cruiser and Toyota Corona. Following the financial growth, Toyota integrated Hino Motors and Daihitsu Motor companies into its structure. Today, the company makes sales in more than 160 countries, owns 69 factories and provides jobs for 340.000 employees (Toyota Resmi İnternet Sitesi, 2019). The company is also active in the fields of marine services, biotechnology, construction and finance.

While Toyota continued its success throughout 2000s, the company experienced a considerable crisis in 2010. The company had to recall its Toyota Camry and Toyota Corolla vehicles, as several car crashes happened due to the possible incursion of an incorrect or out-of-place front driver's side floor mat into the foot pedal well (Frean, 2010). The recall process took two years, as the company had sold more than 55.000 Toyota Camry and Toyota Corolla vehicles. Following the crisis, the CEO of Toyota Motor Corporation, Akio Toyoda, made a press statement in Capital Hill, where he confessed the downsides of their management style: "Toyota has three priorities: Security, quality and production-based growth. Unfortunately, these priorities have changed over time due to managerial problems. Growth has turned into our main and only priority" (Toyoda, 2010).

Toyota is known for following the principles of "Toyota Way", which is based on stability, authoritarian management and sustainable production (Frean, 2010). As a result of the strict hierarchical relations within the company, the warnings made by factory workers regarding the automobile defects were disregarded by the top management (Glionna, 2010). The result of ignoring this mistake has been the loss of 50 lives, who were Toyota consumers. Further research revealed that the defect could be foreseen three years earlier, if required precautions were taken during the production process (Glionna, 2010). Due to the recall process, the company lost more than 100 million dollars in a two-year period (Frean, 2010). The company also had to pay 1.2 billion fines to the families of Toyota consumers who lost their lives due to the product defects.

The authoritarian management style within Toyota has started to evolve after the recall incident, as the research conducted by Gallup Research Company revealed that $31 \%$ Toyota consumers perceived Toyota automobiles as unsafe, while $35 \%$ stated they lost their confidence in the company (Morgan, 2010). The situation also impacted on the sales, as the company sold $\% 9$ less automobiles following the recall crisis.

One of the primary attempts made by Toyota CEO Akio Toyoda has been to be transparent about automobile production processes and the lessons drawn from the deadly recall incident. The company has provided footages and information regarding the production procedures on their official website, while also sharing the risk management strategy they curated after the recall experience. The company is also sensitive regarding contemporary crisis companies may face, such as cyberattacks

Research Article - This article was checked by iThenticate 
and consumer privacy. The Toyota Sustainability Data Book (2018) details how Toyota manages big consumer data sets and take security measures to prevent external attacks.

Overall, the recall incident has become a major lesson, especially for the top management of Toyota. As a grounded automobile company, with a long history of production, the recall experience revealed that Toyota had to update its authoritative leadership approach and become more accessible for actors in the lower steps of the company hierarchy.

\section{The Case with Facebook}

2000s were marked for the emergence of various online social networks such as Napster, Limewire, YouTube, Facebook and Myspace, thanks to the interactive nature of web 2.0 services. Facebook emerged as one of the most sustainable online social networks, which primarily started as a platform that was solely open to Harvard University students (Curtis, 2014). The platform reach was later expanded to the whole US based universities, and then to the world audience in 2006 (Curtis, 2014). By 2010, the company reached more than 500 million users worldwide and introduced advertising services to provide additional revenues. By 2014, the company was able to compete with Internet conglomerates such as Google and Amazon with its 41-billion-dollar value (Techcrunch, 2010).

Similar to other companies that experience outstanding financial growth, Facebook has encountered several challenges throughout 2010s. One of these challenges was related with Chinese government, who banned the usage of Facebook within the country's territories (Curtis, 2014). Another challenge was experienced as online social networks such as Facebook and Twitter became primary tools for social mobilization during indignados protests in Spain and the Arab Spring in Middle East (Castells, 2013). Still, these challenges remain marginal, when compared with the Cambridge Analytica Scandal that took place in 2014.

Cambridge Analytica Company based in Washington, was primarily analyzing data of Facebook users for advertising purposes. The crisis took place when Aleksandr Kogan, an employee of Cambridge Analytica developed the "This Is Your Digital Life" application, which aimed to explore Facebook users' political preferences (Fortune, 2018). It was later revealed that the application was developed for political purposes in support of the Donald Trump's presidential candidacy. The psychographic analysis enabled agency employees to direct Trump ads towards anti-Trump Facebook users. Following the incident, an employee of Cambridge Analytica leaked a presentation file that revealed persuasive political advertising strategies on Facebook (Lewis and Hilder, 2018). The document also included strategies specific for other online social networks such as Google, Twitter, Pandora and Snapchat. Facebook was condemned for selling users' data to third parties, without receiving open permission from users (Fortune, 2018).

Mark Zuckerberg, the founder of Facebook, can be identified as a transactional leader. Compared to visionary leaders in the technology sector such as Elon Musk (CEO of Tesla Company) and Jeff Bezos (founder of Amazon), Zuckerberg's business activities have been solely limited with Facebook and its side services in fifteen years. His transactional leadership approach is also apparent in his post-crisis statement, which indicated that neither Zuckerberg nor his company were ready for handling such an experience: "I am currently working to understand what happened to prevent the same experience to take place again. We have made mistakes, there are more precautionary measures to be taken. We need to move on" (Chang, 2018).

This statement indicates that Zuckerberg has been mainly focusing on business transactions, rather than providing an overall company vision that compass risk and crisis management strategies. As a result of the incident, Facebook lost $18 \%$ value in the stock market while the company was charged 5 billion dollars for invading user privacy (Deutsche Welle, 2019). The charge remains the largest 
fine given to a technology company in history. Moreover, post-crisis research revealed that $66 \%$ of Facebook users lost confidence in Facebook in terms of protecting user privacy (Waisbaum, 2018). The Cambridge Analytica Scandal is also a Facebook scandal, as the stolen data belong to Facebook users. As a transactional leader, Zuckerberg responded too late to manage the ongoing incident, and was not equipped to persuade the global Facebook audience. Despite Zuckerberg apologized from the global public several times via Washington Post and CNBC dailies, the daily interaction on Facebook platform decreased by \%20 following the scandal (Hern, 2019).

\section{The Case with United Airlines}

In April 10, 2017, the United Airlines, one of America's major airline companies, encountered a critical crisis when a video appeared on social media that displayed a violent attack against a passenger who was removed from United Airlines Flight 3411 bound for Kentucky. The passenger was David Dao, a 69-year-old Vietnamese American doctor, whose face was covered with blood following the attacks of four Chicago Department of Aviation security officers (Passy, 2017). The company CEO, Oscar Munoz, released a press statement via the official The United Airlines Twitter page following the incident:

"This is an upsetting event to all of us here at United. I apologize for having to re-accommodate these customers. Our team is moving with a sense of urgency to work with the authorities and conduct our own detailed review of what happened. We are also reaching out to this passenger to talk directly to him to further address and resolve this situation" (The United Airlines Twitter Page, 2017).

Despite the cold-blooded press statement released by Munoz, which was indicating that the company was working on fixing the issue, an internal correspondence was leaked on the Internet the same day the incident took place. The internal correspondence was including a message from CEO Munoz, who referred to the attacked passenger as "disruptive and belligerent" (Isidore, 2018). Following the leak, the company lost more than $\$ 1$ billion market value on Wall Street in hours (Czarnecki, 2017). As the violent video and the internal United Airlines correspondence became viral on online social networks, Munoz had to appear on Good Morning America, one of the most watched morning television shows in the United States, where he stated he was ashamed by the violent attacks. In less than four days, the company loss equaled more than $\$ 2$ billion (Czarnecki, 2017). Despite the company representatives explained they revised their overbooking policy, which stated crew members could not remove passengers that were already seated, two different opinion polls conducted by Morning Consult and LandEdu revealed more than $40 \%$ of millennials would not prefer flying with the United Airlines anymore due to the violent incident (Passy, 2017). Within the same month the attack took place, Munoz also apologized at the United States Congress, stating, "We had a horrible failure" (Isidore, 2017). Still Munoz's apology did not change the negative attitude neither towards the incident nor the company.

The United Airlines remains as one of the oldest airline companies in the world, which started its operations in 1920s under the name, Varney Air Lines. The company experienced a steady growth until late 1990s, as the United Airlines controlled almost 54\% of the airline market in the world (Britannica, 2020). September 11, 2001, terrorist attacks, however, negatively influenced the financial power of the company, as many world citizens were skeptical towards flying for being afraid experiencing a similar attack. As a result, the company filed bankruptcy in 2002 and reemerged from bankruptcy protection in 2006 (Britannica, 2020).

Considering the long history of the airline company, one crisis remains predictable. However, throughout 2010s, the way United Airlines was recalled by airline passengers have started to change (LeBeau,2019). While the company was once known for its long and steady history, the United Airlines became a symbol of passenger dissatisfaction. For instance, in 2008, Canadian musician David Carroll wrote a song for the airline company, titled, "United Breaks Guitars", which was based

Research Article - This article was checked by iThenticate 
on his real-life experience telling how his guitar was broken during a flight with the United Airlines. The video was viewed by approximately 500.000 times on YouTube in less than a week and turned into a public relations embarrassment (Jameson, 2009). The company has also been under attack several times, prior to the violent incident, for crises related to overbooking and customer complaints (LeBeau, 2019).

Still, the United Airlines experienced a steady growth until the violent attack under the management of Munoz. Oscar Munoz, who became the CEO of the company in September 2015, was recognized as "a good and caring communicator" for responding to the demands of various stakeholders effectively (Murphy Jr., 2018). However, critics accused Munoz, for remaining as a transactional leader, who focused solely on human resources issues, and lacked a company vision (LeBeau, 2019). One can recall incidents such as the Facebook Cambridge Analytica Scandal and Samsung Note 7 explosion crises, and recognize how the companies and their CEO's with transformative leadership qualities were able to sustain their reputation and survive the future of their companies thanks to their vision. Thus, the United Airlines incident reveals that the transactional leadership style does not remain efficient in terms of responding the demands of various stakeholders.

\section{CONCLUSION}

The cases analyzed in this study underline that effective leadership has great importance for companies, especially during crisis communication and management processes. Firstly, the examples with Martha Stewart Living Omnimedia and Toyota indicate that leaders should be transparent about their financial actions and abstain from questionable investments. Unethical financial transactions, lack of innovation, product defects and unsatisfactory customer service can inevitably result with negative consequences and severe crises. For example, Apple has gained a sustainable advantage in the mobile device industry since mid 2000s. The main success lies behind the company's motivation to upgrade its existing products and services via research and innovation. Even though rivals of Apple, such as Samsung and Huawei have gained momentum in the last decade, it can be observed that iPhone still remains one of the most preferred mobile devices thanks to effective research and development processes. While Apple remains as a successful case, one can consider how BlackBerry lost its customer base, due to various security scandals and software bugs, despite being one of the primary competitors of iPhone in its primary years.

Secondly, the cases examined in this article reveal that leaders should act in cooperation with their internal and external stakeholders. Leadership is often regarded as a one-individual act, which is a misconception. The establishment of effective feedback mechanisms from internal and external stakeholders remain at the heart of successful leadership. Especially in an age marked by the intense usage of new information and communication technologies (ICTs), feedback mechanisms can be established with lower costs and the integration of high-tech analytical services. As revealed with the cases of Facebook and the United Airlines, companies can face severe negative reactions, if corporate leaders handle situations solely in line with their own wishes.

Lastly, the cases analyzed in this study reveal that corporate leaders should remain as reliable figures, and act in accordance with the business ethics codes. Transparency and accessibility are key values, when it comes to ethical codes related with corporate leadership. Companies should be well-prepared against potential crisis scenarios, so that ethical values can be preserved during chaotic periods of crisis management processes. Corporate leaders need to continue considering the interests and demands of the company stakeholders even during tough times. It should also be recognized at this point that even a stakeholder (i.e. suppliers, investors or consumer groups) of a company can be the source of crisis itself. Thus, the quality of business partnerships determines the future of company and its leader(s). The Martha Stewart Living Omnimedia example reveals that Stewart made questionable decisions while investing in the stock market, by purchasing ethically questionable market shares of a medical company. This experience shows that a corporate leader can only

Submit Date: 20.07.2020, Acceptance Date: 03.09.2020, DOI NO:10.7456/11004100/020

Research Article - This article was checked by iThenticate

Copyright (C) The Turkish Online Journal of Design, Art and Communication 
legitimize her/his presence and influence by curating a transparent communication strategy, based on ethics, interaction and effective feedback mechanisms.

\section{REFERENCES}

Akım, F. (2005). Liderin/Yöneticinin Kriz İletişimindeki Rolü ve Önemi (Yayımlanmış Yüksek Lisans Tezi). İstanbul Üniversitesi.

Allen, L. (2006). Being Martha: The Inside Story of Martha Stewart and Her Amazing Life. Wiley.

Balaban, S. (2018). Kriz Yönetiminde Liderlik ve Liderlik Özelliklerinin Kriz Yönetimine Etkisi Üzerine Bir Araştırma (Yayımlanmış Yüksek Lisans Tezi). İstanbul Gelişim Üniversitesi.

Bass, B.M., Avolio, B.J., Jung, D.I. \& Berson, Y. (2003). Predicting Unit Performance By Assessing Transformative and Transactional Leadership. Journal of Applied Psychology, 88(2), 207-218.

Bono, J.E. \& Judge, T.A. (2004). Personality and Transformative and Transactional Leadership. Journal of Applied Psychology, 89(5), 901-910.

Burns, J. M. (1978). Leadership. New York: Harper \& Row.

Byron, C.M. (2002). Martha Inc.: The Incredible Story of Martha Stewart Living Omnimedia. Wiley.

Castells, M. (2013). İsyan ve Umut Ağları. Koç Üniversitesi Yayınları.

Chang, A. (2018, May 02). The Facebook and Cambridge Analytica scandal, explained with a simple diagram. Vox, https:// www.vox.com/policy-and-politics/2018/3/23/17151916/ facebookcambridge-analytica-trump-diagram adresinden erişilmiştir.

Coombs, W. T. (2004). Impact of Past Crises on Current Crisis Communication: Insights From Situational Crisis Communication Theory. The Journal of Business Communication, 41(3), 265289.

Curtis, S. (2014, February 03). Facebook at 10: Zuckerberg hails incredible journey. The Telegraph. https://www.telegraph.co.uk/technology/facebook/10614544/Facebook-at-10-Zuckerberg-hails-incredible-journey.html adresinden erişilmiştir.

Czarnecki, S. (2017, June 06). Timeline of a crisis: United Airlines. PR Week. https://www.prweek.com/article/1435619/timeline-crisis-united-airlines adresinden erişilmiştir.

Deutsche Welle. (2019, July 24). ABD'de Facebook'a rekor ceza. https://www.dw.com/tr/abddefacebooka-rekor-ce-za/a-49732681 adresinden erişilmiştir.

Diamond, J. (2016). Power: A User's Guide. Santa Fe, NM: Belly Song Press.

The Economist. (2003, September 12). Face Value: Cooking Martha's Goose. https://www.economist.com/taxonomy/term/108?page=782 adresinden erişilmiştir.

Fortune. (2018, April 10). Cambridge Analytica Scandal: 10 questions answered. https://fortune.com/2018/04/10/facebo-ok-cambridge-analytica-what-happened/ adresinden erişilmiştir.

Frean, A. (2010, March 10). Investigators to look into Toyota in-cident. The Times, https://www.thetimes.co.uk/article/ investigators-to-look-into-toyota-incident-wf8nwlhqcjd adresinden erişilmiştir.

Future of Working. (2015). 7 Famous Authoritarian Leaders. 23 Kasim 2019 tarihinde https://futureofworking.com/7-famous-authoritarian-leaders/ adresinden erişilmiştir.

Gladwell, M. (2008). Outliers: The Story of Success. Little, Brown an Company. 
Glionna, J.M. (2010, March 08). Toyota workers raised safety con-cerns with bosses in 2006 memo. LA Times, https://www. latimes.com/archives/la-xpm-2010-mar-08-la-fi-toyota-canaries82010mar08-story.html adresinden erişilmiştir.

Guo, L., Decoster, S., Babalola, M., De Schutter, L., Garba, O.A., \& Riisla, K. (2018). Authoritarian Leadership and Employee Creativity: The Moderating Role of Psychological Capital and the Mediating Role of Fear and Defensive Silence. Journal of Business Research, 92, 218-230.

Hemphill, J. K. (1949). Situational Factors in Leadership. Columbus: Ohio State University, Bureau of Educational Research.

Hern, A. (2019, June 20). Facebook usage falling after privacy scandals, data suggests. The Guardian, https://www.theguardian.com/technology/2019/jun/20/facebook-usage-col-lapsed-sincescandal-data-shows adresinden erişilmiştir.

Hogg, M.A. \& Adelman, J. (2013). Uncertainty-Identity Theory: Extreme Groups, Radical Behavior and Authoritarian Leadership. Journal of Social Issues: A Journal of the Society for the Psychological Study of Social Issues. 69(3), 436-454.

Jackson-Cherry, L.R. and Erford, B.T. (2017). Crisis Assessment, Intervention and Prevention. Pearson.

James, R.J. \& Lane, K.E. (2020). "Blurred Lines”: Reflections of the Criminal Hero Figure. Criminals as Heroes in Popular Culture. In: James R., Lane K. (eds) Criminals as Heroes in Popular Culture. Palgrave Pivot, Cham.

Jameson, A. (2009, June 09). Musician Behind the Anti-airline Hit Video 'United Breaks Guitars' Pledges More Songs. https://www.telegraph.co.uk/travel/travelnews/5892082/Musician-behind-anti airline-hit-video-United-Breaks-Guitars-pledges-more-songs.html adresinden erişilmiştir.

Jerome, A. M., Moffitt, M. A., and Knudsen, J. W. (2007). Understanding How Martha Stewart Harmed Her Image Restoration Through a "Micropolitics" of Power J. L. Courtright, \& P. M. Smudde (Der.), Power and Public Relations içinde (pp. 85-105). Cresskill, NJ: Hampton Press, Inc.

Isidore, C. (2017, May 02). United CEO: 'We Had a Horrible Failure'. CNN Business. https://money.cnn.com/2017/05/02/news/companies/united-ceo-munozcongress/index.html adresinden erişilmiştir.

Kirchmayer, Z. \& Fratricova, J. (2020). What Motivates Generation Z at Work? Insights into Motivation Drivers of Business Students in Slovakia. Innovation Management and Education Excellence through Vision 2020 Conference Proceedings.

LeBeau, P. (2019, December 05). United's Oscar Munoz to Step Down as CEO,

President Scott Kirby Will Take Over. CNBC. https://www.cnbc.com/2019/12/05/oscar-munoz-tostep-down-as-ceo-of united airlines-ual.html adresinden erişilmiştir.

Ledbetter, J. (2008, June 11). Why Martha Stewart's Company is Doomed. Slate. https://slate.com/business/2008/06/why-martha-stewarts-company-is-doomed.html adresinden erişilmiştir.

Lewis, P. \& Hilder, P. (2018, March 23). Leaked: Cambridge Analytica's blueprint for Trump Victory. The Guardian, htt-ps:/www.theguardian.com/uk-news/2018/mar/23/lea-ked-cambridgeanalyticas-blueprint-for-trump-victory adresinden erişilmiştir.

Li, Y. \& Sun, J. (2015). Traditional Chinese Leadership and Employee Voice Behavior: A CrossLevel Examination. The Leadership Quarterly, 26(2), 172-189.

Moore, B. V. (1927). The May Conference on Leadership. Personnel Journal, 6, 124128. 
Morgan, D. (2010, March 02). Poll says 31 percent of Americans believe Toyota unsafe. Reuters. https://www.reuters.com/article/us-toyota-poll/poll-says-31-percent-of-ameri-cans-believe-toyotasunsafe-idUSTRE62121B20100302 adresinden erişilmiştir.

Murphy Jr., B. (2018, March 27). United Airlines' CEO's Response to the Company's Recent Incidents Demonstrates a Key Leadership Quality. The Business Insider.

https://www.businessinsider.com/6-words-from-the-ceo-of-united-airlines can-teach-us-aboutleadership-2018-3 adresinden erişilmiştir.

NBC. (2004). Can Martha Turn Her Business Around?

http://www.nbcnews.com/id/7068355/ns/business-us_business/t/can-martha turn-her-businessesaround/ adresinden erişilmiştir.

Özdemir, Ö. (2017). Kriz Yönetimi ve Samsung Note 7 Örneklemesi. Açı̈ögretim Uygulamaları ve Araştırma Dergisi, 3(1), 110-128.

Passy, J. (2017, April 22). Survey: Nearly Half of Young Americans Say They Won’t Fly United Anymore. https://www.marketwatch.com/story/nearly-half-of-young-americans-wont-fly-unitedanymore-2017-04-21 adresinden erişilmiştir.

Rosener, J. B. (2011). Ways Woman Lead. Leadership, Gender and Organization, 27, 19-29.

Sebastian, M. (2015, June 22). Martha Stewart Living Omnimedia Sold for \$353 Million. Adage. https://adage.com/article/media/martha-stewart living-omnimedia-sold-353-million/299155 adresinden erişilmiştir.

Seeman, M. (1960). Social Status and Leadership. Columbus: Ohio State University,Bureau of Educational Research.

Shields, C.M. \& Hesbol, K.A. (2020). Transformative Leadership to Inclusion, Equity and Social Justice. Journal of School Leadership, 30(1), 3-22.

Stake, R.E. (1978). The Case Study Method in Social Inquiry. Educational Researcher, 7(2), 5-8.

Tichy, N.M. and Devanna, M.A. (1986). The Transformational Leader: The Key to Global Competitiveness. Wiley.

Techcrunch. (2010, July 21). Zuckerberg makes it official: Facebook hits 500 million members. https:// techcrunch.com/2010/07/21/facebook-500-million/ adresinden erişilmiştir.

Toyota Resmi İnternet Sitesi. (2019). http://www.toyota.com.tr adresinden erişilmiştir.

Toyota Sustainability Data Book. (2018). https://global.toyota/ pages/global_toyota/sustainability/report/sdb/sdb18_139-142_en.pdf adresinden erişilmiştir.

Toyotaky.com (2019). http://toyotaky.com/history.asp adresinden erişilmiştir.

Ulutaş, S. (2010). Kriz Yönetimi ve Dönüşümcü Liderlik (Yayımlanmış Doktora Tezi). DEÜ Eğitim Bilimleri Enstitüsü.

The United Airlines Twitter Page. (2017). https://twitter.com/united adresinden erişilmiştir.

Young, H.R., Glerum, D.R., Joseph, M. (2020). A Meta-Analysis of Transactional Leadership and Follower Performance: Double-Edged Effects of LMX and Empowerment. Journal of Management, https://doi.org/10.1177/0149206320908646

Waisbaum, H. (2018, April 18). Trust in Facebook has dropped by 66 percent since the Cambridge Analytica scandal. ht-tps://www.nbcnews.com/business/consumer/trust-fa-cebook-has-dropped-51percent-cambridge-analyti-ca-scandal-n867011 adresinden erişilmiştir. 
The Turkish Online Journal of Design, Art and Communication - TOJDAC

ISSN: 2146-5193, October 2020 Volume 10 Issue 4, p.597-611

Wang, H. \& Guan, B. (2018). The Positive Effect of Authoritarian Leadership on Employee Performance: The Moderating Role of Power Distance. Frontier Psychology,

https://doi.org/10.3389/fpsyg.2018.00357

White, B. and Masters, B. A. (2004, January 20). Poll Indicates Perception of Guilt. The Washington Post, p. E1. 